RESEARCH ARTICLE

\title{
An Analytical study on Continuance Level of TNAU Recommended Technologies among the Tapioca Growers
}

\author{
Kothainayagi T.N ${ }^{* 1}$ and Murugan P.P ${ }^{1}$ \\ ${ }^{* 1}$ Department of Agricultural Extension and Rural Sociology, Tamil Nadu Agricultural University, Coimbatore - 641003.
}

Received : $12^{\text {th }}$ February, 2020

Revised : $25^{\text {th }}$ February, 2020

Accepted : $07^{\text {th }}$ March, 2020

\begin{abstract}
New agricultural technologies are need to increasing the production and productivity of agricultural crops. Technological change has been the major driving force for increasing agricultural productivity. It was found from different study that growers' perceptions of technology characteristics significantly affect their adoption decisions. The technology which was adopted at one time may be discontinuing in other time in different way. This study identified the reason for discontinuance of TNAU recommended practices among tapioca growers. Salem and Namakkal district of Tamil Nadu have been chosen as it records top in area covers under tapioca cultivation. The growers were selected by following Proportionate Random Sampling procedure. Accordingly, 129 tapioca growers were selected as growers for the study. From the study it was found that majority of growers completely discontinued the nursery management practices. Except bio fertilizer, fungicide usage, recommendations for mealy bug, cassava mosaic and TNAU recommended varieties all other technologies still followed by tapioca growers.
\end{abstract}

Keywords: Technological change, discontinuance, recommended practices, tapioca.

\section{INTRODUCTION}

Tapioca (Manihot esculenta) was introduced in India during the later part of the 18th Century. This crop has the ability to grow under adverse conditions without any crop failure. This is one of the most drought-tolerant crops, can be successfully cultivated on marginal soils and gives reasonable yields where many other crops do not grow well and hence it has earned the reputation as a "famine reserve crop".

Cassava is the main source of calories for 500 million people across the globe India is one among the largest producers of cassava in the world and ranks tenth position in area (0.173 million ha) with the production of 4.95 million tonnes (FAO, 20182019). In India, major cassava growing states are Tamil Nadu, Kerela, Andhra Pradesh with production of 2.862 tonnes, 1.72 tonnes, 1.92 tonnes respectively (INDIASTAT, 2018-2019).

Among the states, Tamil Nadu is leading in the production of cassava and trend shows the importance of cassava among root crops in Tamil Nadu to the contribution to State's GDP. Namakkal district places first position in Cassava production which covers an area of $(16,150$ ha) which is followed by Salem district (12,223 ha). Other areas cultivating tapioca for culinary purposes were Trichy, Cuddalore, Karur, Tiruvannamalai and Kanyakumari districts (State Department of Horticulture).

Since 1977, TNAU released cassava varieties and technologies for tapioca such as C01, CO2, C03, CO TP (4), CO TP(5), Tapioca YTP1 and YTP 2 were released from Tapioca and Castor Research Station, 2020. The existence of Tapioca and Castor Research Station in Salem district is helpful in serving the growers and to bring transformation in cassava cultivation among the growers. Studies on the determinant factors to the adoption of agricultural technologies are abound but there is dearth of information on the factors that predispose growers to discontinue the adoption of innovation.

Ganesh Das (2018) resulted that majority of the respondents' discontinued the technology of low cost azolla Production (52.00\%), followed by Zero tillage, bio technology of wheat (22.00\%) and SRI method of Paddy production (10.00\%).

Arikpo (2010) work on analysis of propensity to discontinue the adoption of yam mini sett technology among small scale growers shows factors which contribute to discontinuance level were extension agency contact (1.00\%), input availability (5.00 
\%) and feedback provision (10.00\%) while attitude and marketability had no impact. This study deals with one of the objectives of the study such as discontinuance level of recommended practices among the tapioca growers.

\section{MATERIAL AND METHODS}

The design of research is the most important and critical aspect of research methodology. Ex-post facto research design was used in this study to assess the discontinuance level of recommended varieties and technologies which is most suitable for the objectives and type of information needed.

In Tamilnadu, Salem and Namakkal districts were in top places of tapioca cultivation under area wise. Considering this data as the criteria, these two districts were selected purposefully for the study. In this two district, one block such as Namagiripettai from Namakkal, Pethanayakkanpalayam from Salem district were chosen according to highest area under tapioca cultivation. Two villages from each block (Altogether four villages) were also selected randomly. A sample of 129 growers was selected from four villages following Proportionate Random Sampling technique. Data were collected with the help of a well-structured and pre-tested interview schedule and analyzed with suitable statistical techniques such as percentage analysis.

\section{RESULTS AND DISCUSSION}

Rogers (2003) reported that two types of discontinuance which can be replacement discontinuance that is rejecting an idea in order to adopt a better one that supersedes it or disenchantment discontinuance when a decision to reject an idea as a result of dissatisfaction with its performance.

The extent of discontinuance was measured for only those growerswho had adopted the recommended cassava production technologies such as crop production, crop protection technologies for the last three years.

From the Table 1, it is evident that an majority (99.23\%) of tapioca growers who adopted the recommended season for tapioca cultivation were still following the recommended practices only during that particular season. It shows that recommended practices were suited for majority of growers and which produce tubers at harvest stage in a timely manner. The recommended varieties such as C01, CO2, CO3 and Tapioca YTP1 of tapioca among the growers almost cent per cent of the growers (100.00\%) were partially discontinued. This is because of unavailability of tapioca setts among the growers. As Mulluvadi 1, kunguma Rose was the predominant variety existing in the study area, growers utilized the Mulluvadi 1, kunguma Rose those setts available in abundance at the planting stage of tapioca cultivation.

While considering the land preparation, most of growers $(84.37 \%)$ were yet adopting the recommended time of ploughing. This level of adoption might be due to awareness of ploughing time. Followed by more than one-tenth of growers (15.63\%) were partially discontinued. The reason behind that are growers satisfied the average time of ploughing as 2- 3 time and cost involved in ploughing practices.

Nearly one-fourth (24.24\%) of the growers yet continuing the recommended practice of ridges and furrows formation because of water availability. Little more than half of the majority $(56.06 \%)$ were partially discontinued the practices and almost one fifths (19.69\%) of the growers fully discontinued this practice because of using drip irrigation and laborious work. Level of continuance in case of soil depth is practiced by majority of growers (97.54\%). The reasons behind this continuance level were suitability. Only a lesser per cent (2.45\%) were partially discontinued this practices because of non tangible benefits.

Nearly one-fourth (18.00\%) of growers were yet continuing formation of nursery and transplanting for the reason that reduce the gap filling rate. Followed by nearly one -third (32.00\%) of the growers and half of the growers(50.00\%) were partially and completely discontinued technologies respectively. This is because of reason that raising nursery for rouging of Cassava Mosaic Virus infected setts involves riskiness associated with these practices. This discontinuance might be due to reason of tapioca growers might felt this practices as more time consumed one. By following this practices labor charge would increase.

Level of continuance for usage of setts cutter shows an overwhelming of majority of the growers (99.20\%). This adoption rate revealed that there is no possible best alternatives while compared with recommended one. Little more than one -third of growers (36.06\%) who previously adopted sett treatment with fungicide practice were continuing due to low incidence of diseases. Nearly onethird (31.14\%) of growers partially adopted due to unavailability of inputs in nearby area and also lack of awareness about its effect.

Nearly one -fourth (18.00\%) of the growers were adopting the bio fertilizers because of awareness and knowledge level on its advantages. More than half of the growers (56.25\%) partially discontinued the practice of sett treatment with bio fertilizer as these were time consuming practices and it consumed more labor. One - fourth of the majority growers $(25.00 \%)$ were fully discontinued sett 
treatment with bio fertilizers for the reason that growers are not ready to adopt those technologies. This indicates that existence of lack of awareness among the growers. These lacunae overcome by creating more awareness among farming community about mobile based SMS advisories (Murugan, 2017).

Table 1.Distribution of Respondents according to the continuance level of crop production technologies $n=129$

\begin{tabular}{|c|c|c|c|c|c|c|c|c|}
\hline \multirow{2}{*}{$\begin{array}{l}\text { Recommended } \\
\text { Technologies }\end{array}$} & \multirow{2}{*}{$\begin{array}{c}\text { No. of } \\
\text { adopters }\end{array}$} & \multirow{2}{*}{$\begin{array}{c}\text { No. of } \\
\text { adopters in \% }\end{array}$} & \multicolumn{6}{|c|}{ Discontinuance } \\
\hline & & & *F.D & F.D in $\%$ & *P.D & P.D in \% & $*$ L. C & L.C in \% \\
\hline Season & 129 & 100 & & & 1 & 0.77 & 128 & 99.23 \\
\hline \multicolumn{9}{|l|}{ Varieties } \\
\hline CO 1 & 3 & 2.32 & - & - & 3 & 100 & - & - \\
\hline $\mathrm{CO} 2$ & 2 & 1.55 & - & - & 2 & 100 & - & - \\
\hline $\mathrm{CO} 3$ & 3 & 2.32 & - & - & 3 & 100 & - & - \\
\hline CO TP(4) & - & - & - & - & - & - & - & - \\
\hline co TP(5) & - & - & - & - & - & - & - & - \\
\hline Tapioca YTP 1 & 32 & 24.80 & - & - & 32 & 100 & - & - \\
\hline \multicolumn{9}{|l|}{ Land Preparation: } \\
\hline Number of average times ploughing & 128 & 99.22 & & & 20 & 15.63 & 108 & 84.37 \\
\hline Formation of ridges and furrows & 66 & 51.1 & 13 & 19.69 & 37 & 56.06 & 16 & 24.25 \\
\hline Soil depth & 122 & 94.5 & - & - & 3 & 2.45 & 119 & 97.55 \\
\hline \multicolumn{9}{|l|}{ Nursery management } \\
\hline $\begin{array}{l}\text { Raising nursery for rouging of Cassava } \\
\text { Mosaic Virus infected setts }\end{array}$ & 50 & 38.75 & 25 & 50 & 16 & 32 & 9 & 18 \\
\hline Nursery Area & 50 & 38.75 & 27 & 54 & 14 & 28 & 9 & 18 \\
\hline Sett preparation using Kuchi cutter. & 126 & 97.67 & - & - & 1 & 0.80 & 126 & 99.20 \\
\hline \multicolumn{9}{|l|}{ Sett treatment: } \\
\hline Sett treatment with fungicides & 61 & 47.28 & 20 & 32.80 & 19 & 31.14 & 22 & 36.06 \\
\hline Sett treatment with bio fertilizer & 16 & 12.40 & 4 & 25 & 9 & 56.25 & 3 & 18.75 \\
\hline Transplanting & 50 & 38.75 & 27 & 54 & 14 & 28 & 9 & 18 \\
\hline Sett Rate & 114 & 88.37 & & & 6 & 5.26 & 108 & 94.74 \\
\hline Spacing & 106 & 82.17 & & & 9 & 8.49 & 97 & 91.51 \\
\hline Irrigation management & 47 & 36.43 & 2 & 4.25 & 4 & 8.51 & 41 & 87.24 \\
\hline Intercropping & 38 & 29.45 & 23 & 60.54 & 11 & 28.94 & 4 & 10.52 \\
\hline \multicolumn{9}{|l|}{ Manures and Fertilizers: } \\
\hline Quantity of Farm Yard Manure (25t/ha) & 115 & 89.14 & & & 10 & 8.70 & 105 & 91.30 \\
\hline Basal (NPK) & 119 & 92.24 & & & 6 & 5.04 & 113 & 94.95 \\
\hline Bio fertilizer & 23 & 17.82 & & & 23 & 100 & - & - \\
\hline Top dressing (Nitrogen \& potassium) & 118 & 91.47 & 3 & 2.54 & 1 & 0.85 & 114 & 96.61 \\
\hline Time of application & 119 & 92.24 & & & 10 & 8.41 & 109 & 91.59 \\
\hline Micronutrient treatment & 10 & 7.75 & & & 7 & 70 & 3 & 30 \\
\hline $\begin{array}{l}\text { Fertigation } \\
\text { Crop stage }\end{array}$ & 82 & 63.56 & & & 6 & 7.31 & 76 & 92.69 \\
\hline Weed management & 109 & 84.49 & 4 & 3.66 & 9 & 8.27 & 96 & 88.07 \\
\hline \multicolumn{9}{|l|}{ Harvesting } \\
\hline Symptoms of harvest & 126 & 97.67 & & & & - & 126 & 100 \\
\hline Time of harvest & 123 & 95.34 & & & 10 & 8.14 & 113 & 91.86 \\
\hline
\end{tabular}

${ }^{*} \mathrm{~F} . \mathrm{D}=$ Fully discontinued $\quad$ P.D $=$ Partially discontinued $\quad$ L.C $=$ Level of Continuance

Majority of the growers $(94.73 \%)$ were still following the recommended sett rate, spacing as it had given better yield for cassava growers and the recommended sett rate gives sufficient space for tuber growth. Only meager per cent of growers modified the sett rate and spacing according to their sett availability. Most of the growers (87.24\%) followed recommended practices because of increased yield and income. Only meager (8.51\%) were partially discontinuing due to scarcity of water.

One-tenth $(10.52 \%)$ of growers yet continuing adoption of intercrop. More than one-fourth (28.94\%) of growers partially discontinued this practices because of less yield. Three-fifths of the growers (60.52\%) fully discontinued intercropping practices as it does not bestow impact in yield and income. If time and seed for intercrop are available, adopter's under partially discontinued level will shift to not discontinued level.

With regard to application of manures and fertilizers, quantity of Farm Yard Manure, basal (NPK), top dressing (Nitrogen \& potassium), majority of growers(94.95\%) who adopt these recommended technologies were still following practices. Only a lesser per cent of growers partially discontinued because of grower's inability to access finanace. In case of bio fertilizers, almost cent per cent (100.00\%) of growers were partially discontinued due to its unavailability in nearby places.

$107|1-3| 108$ 
One-third $(30.00 \%)$ of growers continuing the usage of micro nutrient treatment because of benefits gained. Little less than three-fourths of growers $(70.00 \%)$ were partially discontinued micro nutrient treatment as it is not available in nearby places. Growers of fertigation technology majority of the growers (92.68\%) were yet adopting these practices as it gives better result. In weed management, most of growers $(88.07 \%)$ were yet continuing the practices. A meager (8.25\%) per cent of the growers were partially discontinued. The main reason might be due to scarcity of labor.

With regard to the harvesting practices, cent per cent (100.00\%) of growers were still continuing recommended practices of harvest symptoms. Majority of growers (91.86\%) are yet following recommended practices of harvesting time. Only meager (8.14\%) per cent of growers were partially discontinued. Price fluctuation of market rate might be the main cause for discontinuance.

From the table 2, distribution of growers according to their extent of continuance of crop protection technologies were clearly understood. Almost cent per cent (100.00\%) growers continuing the recommended practices such as usage of disease free setts as input materials. The reason behind this might be usage of disease free setts reduce the diseases incidence.

Table 2.Distribution of Respondents according to the continuance level of crop protection technologies

\begin{tabular}{|c|c|c|c|c|c|c|c|c|}
\hline \multirow[t]{2}{*}{ Recommended Technologies } & \multirow{2}{*}{$\begin{array}{r}\text { No. of } \\
\text { adopters }\end{array}$} & \multirow{2}{*}{$\begin{array}{r}\text { No. of } \\
\text { adopters in \% }\end{array}$} & \multicolumn{6}{|c|}{ Discontinuance } \\
\hline & & & *F.D & F.D in $\%$ & *P.D & P.D in \% & *L.C & L.C in \% \\
\hline Use of disease free setts & 121 & 93.79 & - & - & - & - & 121 & 100 \\
\hline \multicolumn{9}{|l|}{ Pests Management } \\
\hline Red spider mites & 7 & 5.42 & - & - & 1 & 14.28 & 6 & 85.72 \\
\hline Whitefly & 79 & 61.24 & 13 & 16.45 & 16 & 20.25 & 50 & 63.30 \\
\hline Spiralling whitefly & 7 & 5.42 & 1 & 14.28 & 1 & 14.28 & 5 & 71.44 \\
\hline Mealy bug & 24 & 18.60 & 2 & 8.34 & 7 & 29.16 & 15 & 62.50 \\
\hline \multicolumn{9}{|l|}{ Diseases management } \\
\hline Cassava Mosaic & 7 & 5.42 & 4 & 57.14 & 1 & 14.29 & 2 & 28.57 \\
\hline Cercospora Leaf spot & 8 & 6.20 & - & - & - & - & 8 & 100 \\
\hline $\begin{array}{l}\text { Tuber rot management with } \\
\text { Trichoderma Viridi }\end{array}$ & 110 & 85.27 & - & - & 34 & 30.92 & 76 & 69.09 \\
\hline
\end{tabular}

${ }^{*} \mathrm{~F} . \mathrm{D}=$ Fully discontinued $\quad$ P.D $=$ Partially discontinued $\quad$ L.C $=$ Level of Continuance

In pests management, most of the growers $(85.72 \%)$ were following recommended practices to manage red spider mite. The adoption of these practices mainly due to better effectiveness against the pest. Little more than one tenth of growers (14.28\%) were partially discontinued as it is not occurred in last two years. Little more than half of majority of the growers (63.30\%) who fall under the category of growers were continued to adopt the recommended practices of whitefly because of its usefulness. While about one fifth of growers(20.25\%) who previously adopted the recommended practices were partially discontinued due to grounds that recommended practices were not produce expected level of positive effects. Little less than threefourths $(71.44 \%)$ were yet continuing recommended practices as it reduce pests incidence. Only little more than one-tenth(14.28\%) of growers were partially discontinued the practices. Reason for this discontinuance may be lack of awareness. In case of mealy bug more than half of the majority of growers $(62.50 \%)$ who adopted recommended practices were still continuining practices. About 29.16 per cent of growers were partially adopted recommended practices as its effects don't show impact in yield.

In case of disease management, about 28.57 per cent of growers still following recommended practices because of its efficacy and its impact in yield. Only little more than one tenth (14.29\%) of growers partially discontinued recommended practices as it produce less impact. Half of the growers(57.14\%) discontinued completely recommended practices of cassava mosaic. The reason quoted by growers is cassava mosaic diseases impacts don't produce much impact. Almost all the growers(100.00\%) were yet following recommended practices. For this disease, recommended practices are the bestway to eradicate. Little more than half of growers (69.09\%) were yet following the recommended practices but less than one-third of growers (30.92\%) were partially discontinued that depends upon the availability of Trichoderma Viridi.

\section{CONCLUSION}

From the above findings, this study shows that TNAU recommended varieties of tapioca such as C01, CO2, CO3 and Tapioca YTP 1 partially discontinued by growers that might be due to unavailability of setts among the growers. The research station concerned has to make necessary arrangements to ensre availability of tapioca setts. It will further increase the production of tapioca in district wise and this finding is in accordance with (Ezeano, 2016). More training, meetings in familiar places of farmer in order to create more awareness in an early time period of planting. Scarcity of setts 
availability is overcome by research station that should give more setts of the specific variety to many growers in each village that will multiply by the concern growers for future considerations.

With regard to other technologies such as season, land preparation, sett rate, spacing, irrigation management, manures and fertilizers, weed management were majority of growers not completely discontinued the recommended technologies. Bio fertilizers should make avail in the block office that help the growers to utilize in an effective manner. Though tapioca growers were adopted other varieties, growers were adopted only recommended technologies either as such or with some modifications. From the findings, TNAU recommended technologies were still following by the growers because it suited for different area and varieties.

\section{REFERENCES}

Arikpo, E. 2010. Analysis of Propensity to Discontinue the Adoption of Yam Mini sett Technology among
Small scale Growers in Yakurr Local Government Area of Cross River State, Nigeria. International Journal of Agriculture and Food Technology, 4(3): 67-71.

Ezeano, C.I. 2016. Determinant factors to discontinue the adoption of Improved okro production technologies by growers in ivo Local government area of ebonyi state, Nigeria. Indo-Asian Journal of Multidisciplinary Research (IAJMR). 2(5): 24541370.

Ganesh Das. 2018. Adoption and Discontinuation of Innovative Agricultural Technology by the Growers of NICRA Village in Cooch Behar District. Indian Research Journal Extension Education, 18(3): 6-10

Murugan,M. and Karthikeyan,C. 2017. Effectiveness of SMS based Extension Advisories on Growers Adoption Behaviour. Madras Agricultural Journal. 104(1-3): 85-89.

Rogers E.M (2003). Diffusion of Innovations. Fifth Edition. New York: Free Press.

Retrived from https://www.indiastat.com/

Retrived from http://www.fao.org/faostat/en/\#data 